\title{
ACCOUNTING REGULATION FOR NONPROFIT ORGANIZATIONS IN ITALY AND SPAIN: TOWARDS AN EUROPEAN PERSPECTIVE
}

\author{
Claudio Travaglini, Enrico Supino ${ }^{1}$ \\ Juana Fuentes Perdomo, Esther Falcón Pérez ${ }^{2}$
}

Introduction - Nonprofit entities and accounting regulations Accounting regulation for nonprofit entities in Italy - Accounting regulation for nonprofit entities in Spain - Conclusion and proposal: need for a new $E U$ regulation

\section{Introduction}

At European Union institutions level, some documents have recognise difficulties in order to provide a common definition of nonprofit organization, given the diversity of legal systems around European Union, but some common features could be stand out ${ }^{3}$ :

- they don't distribute profits among their members;

- they are voluntarily established and, in general, there is voluntary participation;

- there is a certain level of formal or institutional existence;

- they are independent respect to government or business enterprises,

- their purpose is to play a social role.

According to García et al (2005), in several works regarding to the welfare systems in the European Union four models for the Third Sector has been pointed out: the Anglo-Saxon, Continental, Scandinavian and Mediterranean models. These different types of Third Sector forms present their own characteristic features, with differences regarding to their social role, degree of extension, internal and external variables or legal regimes.

Legal regulations are one of the most relevant features of nonprofit organizations and, particularly, accounting regulations. In this paper, we analyze the accounting regulation for nonprofit organizations from two Mediterranean countries, Italy and Spain, which share several similarities, but also they show several differences.

After this introduction, the second section of the paper is devoted to the characteristic features of nonprofit organizations and how these elements affect to accounting and financial reporting. Following sections are devoted 
to Italian and Spanish accounting regulations for nonprofit entities and, finally, we conclude with a comparison between then.

\section{Nonprofit entities and accounting regulations}

The nonprofit sector plays an essential role in the economic and social reality of Europe; however this is not widely enough known. For this reason, it is convenient to point out the characteristics of these organizations by emphasising those aspects such as their objectives and goals that make them peculiar and independent organizations.

Without doubt, the key feature of these organizations is the lack of a profit purpose. This does not mean that these organizations cannot obtain a profit through the development of their activities, but that this profit cannot be distributed among the owners or managers of the organization. The aim of these organizations is not to seek profit that can be distributed among the members, as happens in any business enterprise, but to obtain a type of gain other than that of economic profit and measured in social, humanitarian, cultural, educational, altruistic, ecological terms, etc.

Due to the particular nature of these organizations, the objectives pursued are hardly compatible with traditional business objectives, such as maximisation of profits. Therefore, it is usual for these organizations to develop their activities by giving services that, due to their nonprofit nature, are not provided by business enterprises. This occurs, for example, with some artistic and cultural activities. It also happens very frequently in the nonprofit sector where activities connected to social services, e.g. social work, are carried out through collaboration, accords or similar agreements between Public Administrations and nonprofit organizations. These particular relationships between nonprofit organizations and Government administrations are one of the characteristics of the Third Sector. These organizations may also enjoy certain tax benefits, for example, exemption from taxes or receipt of subsidies to finance their activities.

Certain phenomena, such as donations are likely to occur in the nonprofit sector: something that rarely occurs in the business sector. These phenomena very frequently involve a significant contribution to the financial support of the organization, serving to guarantee the continuance of their activities. These donations are usually in cash, but they also can take the form of goods, for example, an ambulance or an art collection. One specific feature of the nonprofit sector, is volunteering, where somebody gives his/her time, talent and skills to the organization free of charge. This is one 
of the values identifying the nonprofit sector, particularly in the social and humanitarian area.

Third sector organizations have some particular characteristics that distinguish them from business or public administration. However, they also share some common features with them. For example, these organizations buy goods and services and also provide services and they sometimes sell goods and services. These activities are supported by their corresponding finances, using revenue such as subsidies, grants, contributions, donations or compensation for services, all of which commonly feature in economic circulation. This means that, like business or governmental entities, Third Sector organizations need efficient management of their resources. They also need tools to assess and measure their performance and accomplishment of their mission.

To meet those management challenges, many management techniques and methods that were designed for business are gradually being introduced into Third Sector organizations. However, it should be noted that the special attributes of these organizations could require different procedures, particularly regarding techniques concerning earnings and performance measurement.

Accounting, as an integrated information system to make decisions, can contribute to the improvement of Third Sector management while meeting users' information needs. Thus, donors and members who contribute to the financing of the activities developed by nonprofit entities are the main information users. Donors and members are, together with governmental organizations, the main users to whom financial information provided by Third Sector is devoted.

Obviously, in contrast to investors in business enterprises, donors, members, and governmental organizations do not give money to nonprofit entities in order to gain profits in strictly financial terms. Accordingly, their information needs are not linked to any possible earnings that may be obtained by the organization. These information needs are linked to performance, and how the nonprofit organizations use the subsidies and donations that they receive and to what extent these contributed funds are used for altruistic and philanthropic purposes, since these are the motives of the donations.

Third Sector organizations exist because people trust them. In order to keep that trust it is essential that their economic and financial management be transparent. To that end, nonprofit organizations should provide financial 
information that pays attention to users' needs.

\section{Accounting regulation for nonprofit entities in Italy}

This section offers a picture of the present situation of Third Sector Accounting in Italy, as an illustrative example of a European country. However, we should take into account the fact that nonprofit organizations throughout Europe are very different and heterogeneous ${ }^{4}$.

Financial statements regulation of nonprofit organizations is seriously inadequate, due to a historical lack of attention: nonprofit organizations didn't distribute profits and therefore it was not necessary to regulate them for tax reasons, and the value of having transparency in financial statements and economic operations was considered of secondary importance, even for Third Sector participants.

In Italy the accounting standards don't affect directly to nonprofit entities: they regulate commercial entities and in the last years there is a "convergence process" in which national accounting standards are moving to International Accounting Standards. But all this concern "commercial entities" regulated in V section of Civil Code, non "moral entities" regulated in I section of Civil Code.

In Italy there isn't a "General Chart of Accounts" compulsory which commercial entities have to adopt: every company can use an its own chart of accounts, but it has the obligation to provide some specific information for civil and tax reasons. In nonprofit sector, in the past, nobody asked for a Chart of Accounts. So NPOs freely used to take their accounting regulation from businesses' one without a real contextualization.

The only accounting rule in Civil Code concerning associations, foundations and others "moral institutions" dates from 1941, and require that annual report done by the board has to be approved yearly by the assembly, without giving any kind of direction on how financial statements have to be outlined and without regulate publication or transparency. Only the tax legislation determines income for cases of commercial activity, to identify and tax the produced profit.

The specific promotional legislation on nonprofit organizations (voluntary organizations, social promotion organizations, social cooperatives, social enterprises) issued from 1990, establishes some particular regulations but they don't modify directly the civil regulation so we 
have an overlapping of inadequate regulation.

National law on voluntary organizations requires that they strike their balance as compulsory; they have to show goods, contributions and legacies received and the approval formalities used by the assembly, but it does not present any particular indication on how to organize the book keeping or present financial statements.

For social promotional associations, that are considered to be the legal form of this association system, it is necessary to insert in the constitution that economical and financial reports are compulsory. It is also specified that it has to be approved by members, even if it doesn't indicate how it must be presented or if it has to follow specific rules for publication.

In the past, some organizations used financial statements patterns of profit-oriented entities and others try to use specific models (usually based on cash-basis balance-sheet). Since 90 s a specific approach to financial statements for nonprofit entities was proposed based on their particular activities and different from those of commercial entities (Travaglini, 1995).

This approach developed an income statement pattern showing how resources are provided and used in areas of the NPO's activity; so are separately reported incomes and charges related to:

a) typical or institutional activities

b) promotional and fund-raising activities

c) non-institutional and additional activities

d) financial activities;

e) extraordinary activities;

f) general support activities.

After few years, in 2001, the nonprofit committee instituted by Italian professional accountants' association ${ }^{5}$ accepted this specific approach and issued some "recommendations" that have been increasingly adopted by NPOs and now represent (without be mandatory by law) the "generally accepted best practices" in Italian nonprofit accounting.

The annual report for nonprofit entities includes five components

- balance sheet

- income statement

- explanatory notes

- fund accounting

- board report

The balance sheet provides information about assets, liabilities and the used format is substantially the same of the commercial entities.

The income statement, which has a specific framework and is called 
"Rendiconto gestionale", has the main aim to inform all the stakeholders about how activities are developed in accordance with nonprofit mission to underline the specificity of nonprofit accounting.

As second level, inside this "main destination classification" income and charges are classified in the ordinary way for businesses' income statements: raw material and consumable, services, staff costs, depreciation and others.

Now the presence of a defined format (and the progressive definition of "nonprofit accounting principles") allows an uniform nonprofit financial statement analysis; the general report model can be specified relative to different types of NPOs.

Finally the last "recommendation"6 concerns "performance indicators in nonprofit organizations involved in fund raising 0 receiving public financing" and collect some financial ratio based on previous format.

Explanatory notes, which are specially important for NPOs, are requested with supplemantary information about funds, accounting rules, staff, tax relief, and some more.

The report on fund accounting shows if there are designated funds and their composition at the end of the period and variances (inflows and outflows) during it.

The trustee report relates about how NPOs operated in the period and highlights main facts during it.

No budget information is required by recommendations but to redact in bigger NPOs a budget is a very useful tool to improve internal democracy and to develop advanced management processes.

For nonprofit entities with a gross income lower than $50.000 €$ in the two previous periods, the recommendation is for a "simple cash basis account" with revenues and expenses subjected to the same classification in categories and without the second level classification. For these less NPOs cash basis report is the only requirement requested.

NPOs are compelled to draw financial reports, but they are not compelled to make it public, and people don't have any public registry, or website where they can see and check annual reports. Usually the big nonprofit organizations publish these reports on newspapers and on their websites, but there isn't an obligation to show the report or to deposit it for the public.

\section{Accounting regulation for nonprofit entities in Spain}


This section offers a picture of the present situation of Third Sector Accounting in Spain, an European country with an Accounting model similar to Portugal or to France, based to a General Chart of Accounts.

A few years ago, nonprofit accounting in Spain could be described as very poor and obsolete, but now it can be stated that this situation has changed radically, in so far as accounting regulations are concerned.

With regard to accounting, it is necessary to make a brief reference to the accounting standards setting in Spain. The standards setter is a governmental unit named Instituto de Contabilidad y Auditoría de Cuentas (Accounting and Auditing Institute), commonly referred to as ICAC, which issues compulsory rules regarding accounting and auditing. The main regulation is the Plan General de Contabilidad (Chart of Accounts) which contains the general regulation regarding the annual report. These rules are transposed from European Accounting Directives to Spanish regulation. This Chart of Accounts is a tool to elaborate financial reporting, commonly implemented in a set of financial statements or annual reports.

A basic set of annual reports includes three different statements: a balance sheet, a profit and loss account, and explanatory notes. This condensed information is the main output of accounting information processing in every organization.

A balance sheet provides information about an organization's assets, liabilities and net assets. This report helps readers to assess the organization's financial situation and its ability to continue to provide services.

A profit and loss account or income statement provides information about revenues, expenses, gains and losses. This report helps readers to assess the organization's performance during the period. It is notable that, in the business environment, this report is the most important source of information to resource providers, because these investors look for profit. Of course, persons and organizations that provide resources to philanthropic entities do not look for profit, so this report is not as relevant as it is in the business environment.

Explanatory notes form an appendix in order to extend, complete and comment on the information provided in the balance sheet and the profit and loss account ${ }^{7}$. These notes are especially relevant for nonprofit entities because they could include much non-financial information, such as appointment or dismissal of board members, information about performance, volunteers, donations, etc. 
In order to guide organizations in preparing these financial statements, the Chart of Accounts (Plan General de Contabilidad) provides a set of accounting principles, valuation and measurement rules, and rules about the form and content of the annual reports.

The Chart of Accounts is based on commercial companies and it is compulsory for all business enterprises. Different adaptations have been issued by ICAC for different economic industries, like construction, real estate, water suppliers, electricity companies, and others.

The ICAC issued an adaptation of the general chart of accounts to nonprofit entities organizations and a set of budgetary information rules in 1998. Since 1999 many Spanish nonprofit organizations have been compelled to draw up their accounting reports according to this regulation. It is notable that these rules are compulsory only for fundaciones de competencia estatal (national foundations) ${ }^{8}$ and asociaciones declaradas de utilidad pública (certified "public benefit" associations) ${ }^{9}$.

The vast majority of nonprofit organizations in Spain are not included in those two categories and, consequently, this accounting regulation is not compulsory for them. However, tax rules exact from entities which have received public subsidies to provide financial reporting according to General Chart of Accounts or the correspondent adaptation. So, the adaptation of the general chart of accounts to nonprofit entities organizations is widely used by Third Sector entities in order to observe not accounting but tax regulation.

The ethics codes and good practices guides for Third Sector organizations require an efficient and transparent financial management, so this accounting regulation could provide guidance on the preparation of nonprofit annual reports and budgets by these entities. Chart 1 shows these regulations.

\begin{tabular}{|ll|}
\hline \multicolumn{1}{|c|}{ Adaptation of the general chart of accounts to nonprofit entities } \\
\hline I & Accounting principles. \\
II & Chart of accounts. \\
III & Accounting definitions and relations. \\
IV & Financial Statements. \\
V & Measurement rules. \\
\hline \multicolumn{1}{c|}{ Budgetary information rules } \\
\hline Rule 1 Budget elaboration. \\
Rule 2 Budget structure. \\
Rule 3 Budget elaboration rules. \\
Rule 4 Program budget elaboration rules. \\
Rule 5 Statements of budget outturn. \\
Rule 6 Statements of budgetary information. \\
\hline
\end{tabular}


The adaptation of the Chart of Accounts to nonprofit entities is basically a tool to elaborate financial reporting. This financial reporting generates annual reports, and the adaptation gives guidance about how this information must be formulated.

The adaptation of the Chart of Accounts provides that accounting principles, measurement and valuation rules, and financial statements are not substantially different from the financial reporting model for business enterprises.

It's significant that to apply business accounting principles to nonprofit organizations is a controversial subject for academics. On the one hand, many authors -at the same way by the Spanish adaptation- consider that accounting principles are general for every kind of organization, irrespective of its specific features; on the other hand, others researchers -and many practitioners- defend that nonprofit attributes demand a set of specific accounting principles, different from business accounting principles, because the latter are linked to earnings measurement and, therefore, are not suitable for organizations which not pursuit profits.

Measurement and valuation rules develop accounting principles, so offer few differences for nonprofit organizations: specific rule for historical and artistic assets, donations and subsidies. However, there are not rules for volunteer activity valuation, in spite of volunteering is a key feature for many Third Sector organizations.

Spanish nonprofit organizations have to make and disclose their financial statements in a very similar way to business enterprises -balance sheet, statement of income, explanatory notes-. As a result, the financial reporting by nonprofit entities offers a "business view" of non-business units. This shows clearly in statement of income, which not take into account the different meaning of this concept in nonprofit setting.

In a business activity, net income or earnings is a measure of the capital turnover for shareholders or owners, and a measure of performance. Nonprofit organizations have not owners, so net income is just a measure of the capital maintenance. Earnings amount is not a good indicator of management efficiency, but informs about entity has maintained (or not) its initial capital in order to carry out its activities and accomplishment its objectives.

In our opinion, the income statement established in the adaptation shows several limitations and it is not useful for users, because this 
financial statement hasn't been designed for Third Sector users, but it has been copied from business model.

Regarding to explanatory notes, informative requirements for nonprofit organizations are larger than for business enterprises. In this appendix, Third Sector organizations must provide a statement of source and application of funds, irrespective their size. Moreover, nonprofit organizations must inform about endowment fund, assets related directly to accomplishments of entity's mission, and other informative requirements from Foundations and Associations acts. Also these organizations must explain their budget outturn.

In sum, the financial statements by Spanish nonprofit entities haven't designed for Third Sector organizations and, in consequence, these financial statements don't disclose a suitable financial reporting for them. These financial statements are insufficient in order to meet users' needs.

Moreover, nonprofit organizations must elaborate budgetary information, which is not obligatory for business but is for governmental organizations. The budget is basically a control tool and is especially important for nonprofit organizations.

Budget purpose consists of planning activities for the year to come and informing about whether revenues forecasts are sufficient to finance expenditure forecasts. That's to say that this report helps to evaluate the entity's viability. Moreover, comparing forecasts with what has been achieved, budget becomes an instrument to control management performance. Larger organizations must draw up their budgets listing in detail their different activities and projects.

Budgetary information is directly linked to accountability and stewardship. A comparison between the budgetary forecasts and outcomes provide information about whether or not managers have performed well, in other words, whether they have spent money wisely or not. This is one of the most relevant questions arising in the Third Sector, because of difficulties in measuring how well (or badly) managers have carried out their responsibilities.

In short, Spanish nonprofit organizations have to elaborate two different kinds of accounting information: financial information, as business is required to do, and budgetary information, as governmental entities are required to do. As Rúa and Vara (2001: 113) assert, "the most extensive and expensive information system has been imposed on nonprofit organizations".

Spanish foundations and associations complain because they have to 
draw up financial information in the same way as business are required to do, although they are not business. Moreover, they consider that accounting regulation do not take into account philanthropic activities. They believe that information requirements are going to increase bureaucracy and they are not very sure that accounting information is useful to the disclosure of "public purpose" activities. Despite there criticisms, which in our opinion are fairly right, we also think this accounting regulation could be a useful tool for the management of Third Sector organizations. Nowadays, many Spanish nonprofit organizations still use traditional and obsolete accounting methods, so these regulations could become an opportunity to improve their accounting in particular and management in general. Undoubtedly, annual reports and budgets are going to increase transparency of the financial position of an entity, its activities and management performance.

Third sector organizations need an efficient management since, in this context, accounting plays an important role in the management and control of their resources. Using an accounting information model, even though it is a business model, is better than not to use anyone.

So, financial reporting becomes a basic factor of transparency and legitimation to the community at large.

Regarding to transparency, according to the Foundations and Associations acts, financial reporting from national foundations and certified "public purpose" associations must be audited by external experts who verify its fairness. Furthermore, these organizations may be required to be audited by governmental administrations.

To sum up, Spanish accounting regulation for Third Sector organizations uses an accounting model designed to business enterprises, that is, an accounting model points to earnings measurement. So these organizations have to make and disclose their financial statements in a very similar way to business enterprises.

Nowadays, accounting general regulation in Spain is in a reform process, in order to adapt the General Chart of Accounts to International Financial Reporting Standards (IFRS) from IASB. Next year, ICAC will issue a New General Chart of Accounts, and then all adaptations will have to be changed. This reform process will affect, in future, to Third Sector organizations, and it could be an opportunity to change an information model which hasn't been designed for them. 


\section{Conclusion and proposal: need for a new EU regulation}

The comparison of the Italian and Spanish regulations shows the requirement of an European framework for nonprofit accountability: if we compare other regulations we face to very different regulations due to national histories.

Now we have the chance to promote a convergence process to provide nonprofit entitities, government authorities and donors a minimum level of uniform regulation.

To reach this standard, we have to survey, referring to twenty-five European countries (and in reference to regulation of private for-profit enterprises):

a) nonprofit entities and their civil regulation

b) annual report and additional information requested

c) source and the kind of regulation (law, accounting standards)

d) accounting standards applied (IAS, national, specific)

e) classification of income and charges

f) the forms to fill (balance sheet, income statement, financial statement, budget, explanatory notes)

g) some simplified regulations for little nonprofit

h) transparency and publicity obligations required

i) auditing obligations.

A critical and comparative analisys of national regulations and the definition of minimum data set for nonprofit accountability are a prerequisite for a convergence project for nonprofit accountability in Europe.

\section{References}

Commissione Aziende non profit Consiglio Nazionale Dottori Commercialisti (CNDC) (2002), Documento di presentazione di un sistema di rappresentazione di sintesi delle aziende nonprofit, www.cndc.it European Commission (1997): Communication on "Promoting the role of voluntary organizations and foundations in Europe". Office for Official Publications of the European Communities, Luxembourg.

European Commission (2000): Commission Discussion Paper "The Commission and non-governmental organizations: building a stronger partnership" COM (2000) 11, final, Brussels. 
García, S.; Durán, P.; Salazar, S. and Ventura, A. (2005): The limits of convergence between third sector models in the European Union. An analysis of the legal framework for volunteering in the Mediterranean third sector (Italy, Spain and Portugal). Paper presented at ISTR-EMES First European Conference, Paris, April.

Real Decreto 1643/1990, de 20 de diciembre, por el que se aprueba el Plan General de Contabilidad [General Chart of Accounts].

Real Decreto 776/1998, de 30 de abril, por el que se aprueban las normas de adaptación del Plan General de Contabilidad a las entidades sin fines lucrativos y las normas de información presupuestaria de estas entidades [Adaptation of General Chart of Accounts to Nonprofit Entities].

Rúa, E. and Vara, M. (2001): "La información económico financiera de las fundaciones", Partida Doble, n 124, Julio-Agosto, pp. 92-113.

Travaglini, C. (1995): "Circuiti e schemi di bilancio per le aziende nonprofit: prime proposizioni”, n¹, Nonprofit, Gennaio-Marzo, pp. 23-54. 
1 Dipartimento di Scienze Aziendali - Università di Bologna

2 Dpto. Economía Financiera y Contabilidad - Universidad de Las Palmas de Gran Canaria

3 See European Commission (2000)

4 See European Commission (1997).

5 Commissione Aziende non profit Consiglio Nazionale Dottori Commercialisti (CNDC):

http://www.cndc.it/CMS/Documenti/206 epgnyhiyne.pdf.

6 http://www.cndc.it/CMS/Documenti/1496 lklaywwccf.pdf.

7 For large enterprises, this appendix includes a Statement of Source and Application of Funds.

8 Foundations established in Spain, which carry out their activities within the national territory. They are subject to several controls by the Ministry which supervises their activities (Education, Culture, Health, etc.)

9 Associations which have received an accreditation by the relevant Ministry because their activities are of public benefit. 